\title{
PELAKSANAAN COURTROOM TELEVISION DALAM PERADILAN PIDANA DENGAN AGENDA SAKSI
}

\author{
I Nengah Susrama \\ susramanengah60@gmail.com \\ Fakultas Hukum Universitas Mahasaraswati Denpasar \\ Putu Angga Pratama Sukma \\ angga.sukma21@gmail.com \\ Fakultas Hukum Universitas Mahasaraswati Denpasar
}

\begin{abstract}
ABSTRAK
Konsep courtroom television adalah pelaksanaan sidang terbuka untuk umum melalui stasiun televisi yang disiarkan secara langsung dengan berlandaskan asas sidang terbuka untuk umum, Konstitusi, KUHAP serta UU Pers yang memiliki fungsi pengawasan didalam persidangan perkara pidana. Akan tetapi konsep courtroom television ini dalam pelaksanaannya masih berbenturan dengan rumusan Pasal 160 ayat (1) huruf a KUHAP mengenai pemeriksaan saksi di ruang persidangan seorang demi seorang. Pelasksanaan courtroom television harus menciptakan suatu sistem untuk kolaborasi antara lembaga peradilan, pers, stasiun televisi, stasiun radio atau provider internet dan juga masyarakat demi menegakan check and balances dalam sistem peradilan pidana selain sebagai fungsi pengawasan.
\end{abstract}

Kata Kunci: courtroom television, sidang terbuka untuk umum, pemeriksaan saksi.

\begin{abstract}
The courtroom television concept is the implementation of open public hearings through television stations that are broadcast live based on the principle of an open session for the public, the Constitution, The Penal Procedure Code and the Act of journalist which have a supervisory function in criminal proceedings. However, the courtroom television concept in its implementation still clashes with the formulation of Article 160 paragraph (1) letter a The Penal Procedure Code regarding the examination of witnesses in courtroom one by one. Courtroom television planning must create a system for collaboration between judicial institutions, the press, television stations, radio stations or internet providers and also the public to enforce checks and balances in the criminal justice system other than as a monitoring function.
\end{abstract}

Keywords: courtroom television the hearing is open to the public, examination of witnesses. 


\section{PENDAHULUAN}

Beberapa tahun belakangan ini sudah tidak dapat ditampikan mengenai beberapa kasus yang pernah menghebohkan di Indonesia, salah satunya adalah kasus dengan terpidana Jessica Kumala Wongso, terpidana kasus pembunuhan berencana terhadap Wayan Mirna Salihin. Tak dapat disangkal, bahwa kasus ini begitu tenar dikarenakan pengawalan media elektronik menayangkan secara langsung (live). Tentunya dengan adanya pengawalan media secara langsung ini, dapat menaikan rating penyiaran, memberikan pendidikan kepada masyarakat mengenai hukum acara pidana dan serta mencegah praktik mafia peradilan.

Teknologi berkembang sangat pesat dan tanpa batas, "borderless world", begitu sering dikemukakan untuk menggambarkan betapa cepat dan pesatnya teknologi itu berkembang serta memainkan peranan yang sangat penting terutama dalam teknologi komunikasi seperti: menjadi penghubung antar individu, kelompok komunitas dalam waktu yang amat cepat dan spektakuler tanpa harus menghadirkan pihak pihak yang berkomunikasi hadir berhadapan secara face to face $^{l}$. Pemberlakuan courtroom television ini tidak serta merta mendapat dukungan dari kalangan akademisi dikarenakan ada beberapa kelemahan ketika courtroom television ini diberdayakan. Salah satunya adalah dapat mempengaruhi indepedensi peradilan, membentuk suatu opini di masyarakat, hingga keterangan bersifat subyektif dari saksi. Hal inilah yang mungkin menjadi dilematis dalam pemberlakuan courtroom television, dan perlu diingat kembali sejatinya hukum pidana ialah hukum yang mengatur tentang pelanggaran-pelanggaraan dan kejahatan-kejahatan terhadap kepentingan umum.

Titik beratnya tidak berada pada kepentingan individu, melainkan pada kepentingan-kepentingan umum. Penafsiran kepentingan umum yang bersifat universal ini merupakan bagian dari pengawasan kepada lembaga peradilan demi mencegah terjadinya mafia peradilan. Dan juga sifat ini dapat dilihat pada hakekat hukum pidana, yaitu dalam hal penerapan tidak tergantung kepada kehendak seorang individu (subjektifitas Hakim, Penuntut Umum, Saksi Penyidik dan

${ }^{1}$ Ni Ketut Supasti Dharmawan,, d.k.k., Keberadaan Pemegang Saham Dalam Rups Dengan Sistem Teleconference Terkait Jaringan Bermasalah Dalam Perspektif Cyber Law, (Denpasar: Udayana Master Law Jurnal, Vol. 4 No. 1, 2015), hlm. 190. 
Pembela Terdakwa), yang in concreto langsung dirugikan, melainkan diserahkan kepada pemerintah sebagai wakil dari kepentingan umum.

Pengertian mengenai courtroom television menurut Paul Lambert yakni "...one of central concerns in relation to television courtroom broadcasting is that television cameras or television operators will distract the various people who are required as part of the courtroom process. This includes witnesses, the jury, judges, lawyers and court staff ${ }^{62}$. Menurut peneliti courtroom television adalah pelaksanaan sidang terbuka untuk umum melalui stasiun televisi yang disiarkan secara langsung (live). Hal ini memberikan ruang bagi masyarakat untuk melakukan penilaian mengenai kinerja hakim, jpu, pengacara, polisi dengan system peradilan pidana terhadap tugas dan fungsi kelembagaannya masing masing. Dikarenakan tergerusnya asas peradilan yaitu sederhana, cepat dan biaya ringan masih jauh dari benak masyarakat.

Kehadiran konsep courtroom television dalam ruang persidangan merupakan konsekuensi dari semakin canggihnya teknologi informasi. Keberadaan kamera di ruang persidangan yang mempunyai fungsi untuk menayangkan secara langsung jalan nya persidangan mempunyai efek yang berarti, dikarenakan era digital ditandai dengan percepatan antara pemberi dan penerima informasi ${ }^{3}$ antar waktu dan jarak yang merupakan bagian dari perlindungan Konstitusi Pasal 28 huruf C ayat (1) "Setiap orang berhak memperoleh manfaat dari teknologi demi meningkatkan kualitas hidupnya......" dan Pasal 28 huru F "Setiap orang berhak untuk memperoleh informasi untuk mengembangkan pribadi.......dengan menggunakan segala jenis saluran yang tersedia”.

Tujuan pengembangan courtroom television diharapkan tidak adanya kekuasaan sewenang-wenang (absence of arbitrary power) dalam arti bahwa seseorang hanya boleh dihukum apabila melanggar hukum. Hal ini merupakan gambaran bahwa aktivitas penegak hukum di lembaga peradilan merupakan hal yang sangat menentukan terhadap reputasi hukum itu sendiri. Dengan ditayangkannya sidang dan dapat diikuti secara langsung oleh masyarakat luas

${ }^{2}$ Paul Lambert, Television Courtroom Broadcasting; Distraction Effects And Eye Tracking, (Chicago: The University Chicago Press, 2012) hlm. 1.

${ }^{3}$ Edmon Makarim, Kompilasi Hukum Telematika, (Jakarta:P.T. Raja Grafindo Persada,2003), hlm. 223. 
memberikan kesempatan kepada masyarakat untuk menilai jalannya persidangan bahwa Hakim dalam memutuskan suatu perkara hendaknya semakin mengedepankan rasa keadilan bukan rasa yang lain.

Mengenai jalannya proses persidangan yang paling penting adalah proses pembuktian, dimana proses pembuktian ini apakah terdakwa benar melakukan tindak pidana atau tidak. Pembuktian merupakan penyajian alat-alat bukti yang sah menurut hukum oleh hakim yang memeriksa suatu perkara guna memberikan kepastian tentang kebenaran peristiwa yang dikemukakan. Dalam hal ini Jaksa Penuntut Umum berkewajiban untuk membuktikan peristiwa-peristiwa yang dikemukakan dengan mengajukan alat bukti di muka persidangan untuk dinilai kebenarannya oleh Majelis Hakim. Kemudian Jaksa Penuntut Umum, Penasehat Hukum dan Majelis Hakim melakukan penelaahan hukum.

Menurut M. Yahya Harahap menyatakan bahwa "Pembuktian adalah ketentuan-ketentuan yang berisi penggarisan dan pedoman tentang cara-cara yang dibenarkan undang-undang membuktikan kesalahan yang didakwakan kepada terdakwa. Pembuktian juga merupakan ketentuan yang mengatur alat-alat bukti yang dibenarkan undang-undang dan boleh dipergunakan hakim membuktikan kesalahan yang didakwakan"4. Pasaat terjadinya proses persidangan dengan agenda pembuktian, hakim wajib menganut sistem pembuktian berdasarkan Pasal 183 Undang-Undang Nomor 8 Tahun 1981 Tentang Kitab Undang-Undang Hukum Acara Pidana (KUHAP), yang merumuskan sebagai berikut "Hakim tidak boleh menjatuhkan pidana kepada seseorang, kecuali apabila dengan sekurang-kurangnya dua alat bukti yang sah ia memperoleh keyakinan bahwa suatu tindak pidana benarbenar terjadi dan bahwa terdakwalah yang bersalah melakukannya”. Alat Bukti tersebut terdapat dalam Pasal 184 ayat (1) KUHAP disebutkan mengenai alat bukti yang sah yaitu "a. Keterangan Saksi; b. Keterangan Ahli; c. Surat; d. Petunjuk; e. Keterangan Terdakwa”.

Pada umumnya Alat bukti keterangan saksi merupakan alat bukti yang paling utama dalam perkara pidana, dapat dikatakan tidak ada perkara pidana yang

${ }^{4}$ Yahya M. Harahap, Pembahasan Permasalahan dan Penerapan KUHP: Pemeriksaan Sidang Pengadilan, Banding, Kasasi, dan Peninjauan Kembali, (Jakarta: Sinar Grafika, Edisi Revisi, 2012), hlm. 273. 
luput dari pembuktian alat bukti keterangan saksi dan keterangan ahli. Hampir semua pembuktian perkara pidana selalu bersandar kepada pemeriksaan saksi. Keterangan saksi yang mempunyai nilai adalah keterangan yang sesuai dengan apa yang dijelaskan pada pasal 1 angka 27 KUHAP yaitu "a. yang saksi lihat sendiri; b. saksi dengar sendiri; c. dan saksi alami sendiri; d. serta menyebutkan alasan dari pengetahuannya itu".

Keterangan saksi dalam agenda perkara pidana harus diperiksa satu per satu seperti yang tercantum dalam Pasal 160 ayat (1) huruf a KUHAP yaitu "Saksi dipanggil ke dalam ruang sidang seorang demi seorang menurut urutan yang dipandang sebaik-baiknya oleh hakim ketua sidang setelah mendengar pendapat penuntut umum, terdakwa atau penasihat hukum". Saksi tidak diperbolehkan saling mendengarkan keterangan. Hal ini untuk menghindari saksi saling mempengaruhi sehingga tidak memberikan keterangan yang seharusnya, sebagaimana yang mereka dengar sendiri, mereka lihat sendiri, atau mereka alami sendiri. Apabila diperlukan, hakim dapat menyuruh saksi ke luar dari ruang sidang, sedangkan saksi yang telah diperiksa wajib keluar dari ruang persidangan. Hal ini dilakukan apabila terdapat kemungkinan saksi yang akan diperiksa selanjutnya menjadi tidak bebas, merasa canggung, atau merasa takut dalam memberikan keterangannya apabila didengar oleh saksi lainnya (obyektifitas keterangan saksi).

Keterkaitan pelaksanaan courtroom television dalam peradilan pidana dirasa dapat memberikan pendidikan kepada masyarakat mengenai hukum acara pidana dan mencegah praktik mafia peradilan. Disatu sisi apabila saksi satu dapat melihat keterangan saksi yang lain melalui media televisi dikarenakan ditayangkan secara langsung dapat berbenturan dengan Pasal 160 ayat (1) huruf a KUHAP. Berdasarkan uraian tersebut maka peneliti tertarik untuk mengadakan penelitian dengan perumusan masalah, pertama bagaimanakah landasan yuridis courtroom television dalam peradilan pidana?, dan kedua apakah pelaksanaan courtroom television dalam peradilan pidana dengan agenda saksi? Tujuan dari penelitian ini adalah untuk menganalisa dan mendeskripsikan mengenai pelaksanaan courtroom television dalam peradilan pidana dengan agenda saksi sesuai dengan asas hukum peradilan yakni terbuka dan dibuka untuk umum. 
Penulisan ini menggunakan penelitian hukum normatif, yaitu penelitian terhadap kaedah hukum itu sendiri (Peraturan perundang-undangan, yurisprudensi, hukum adat atau hukum tidak tertulis lainnya) dan asas-asas hukum yang beranjak dari adanya konflik antara konsep courtroom television dengan Pasal 160 ayat (1) huruf a KUHAP. Penulisan ini menggunakan beberapa pendekatan, yakni pendekatan Undang-undang (statute approach), pendekatan perbandingan (comparative approach), pendekatan konseptual (conceptual approach). Penulisan ini menggunakan bahan hukum primer (primary sources) dan bahan hukum skunder (secondary sources) ${ }^{5}$, yang meliputi undang-undang maupun peraturan perundang-undangan sebagai bahan hukum primer dan laporan hukum, catatan hukum, dan karya tulis hukum lainnya yang hanya memiliki kekuatan persuasif sebagai bahan hukum sekunder.

Teknik pengumpulan bahan hukum dalam penelitian ini menggunakan snowball method (metode bola salju). Adapun yang dimaksud dengan metode bola salju adalah metode menggelinding secara terus menerus yang mengacu kepada peraturan perundang-undangan, dan buku-buku hukum dalam daftar pustaka yang yang bertujuan untuk mengkonstruksikan konsep ${ }^{6}$ courtroom television.

\section{PEMBAHASAN}

\section{Landasan Yuridis Courtroom Television Dalam Peradilan Pidana}

Secara historis courtroom television sudah ada di Indonesia pada tahun 2009 dengan terpidana Antasari Azhar sebagai dalang kasus pembunuhan terhadap direktur PT. Putra Rajawali Banjaran Nazarudin Zulkarnaen. Pada tahun 2010 dengan terpidana Angelina Sondakh, telah melakukan beberapa perbuatan yang ada hubungannya sedemikian rupa sehingga harus dipandang sebagai sesuatu yang berkelanjutan yakni selaku penyelenggara negara atau anggota DPR RI yang menerima hadiah atau janji yaitu menerima uang yang seluruhnya berjumlah Rp 12.580.000.000 dan US \$ 2.350.000 dari Permai Group yang sebelumnya telah

${ }^{5}$ I Made Pasek Diantha, Metode Penelitian Hukum Normatid Dalam Justifikasi Teori Hukum, (Jakarta: Prenada Media Group, 2017), hlm. 8.

${ }^{6}$ Anthon F. Susanto, Penelitian Hukum Transformatif-Partisipatoris, (Malang: Setara Press, 2015), hlm. 216. 
dijanjikan melalui Mindo Rosalina Manulang. Adanya 2 case tersebut yang ditayangkan ditelevisi tidak sepenuhnya satu kesatuan yang utuh dan hal tersebut bukanlah siaran langsung. Berbeda halnya dengan pada tahun 2017 dengan kasus terpidana Jessica Kumala Wongso, kasus pembunuhan berencana terhadap Wayan Mirna Salihin, yang ditayangkan secara terus menerus dan langsung. Secara histori Negara Indoensia sudah mulai mengenal konsep courtroom television tetapi memang dalam pelaksanaanya belum sepenuhnya utuh dikarenakan masih terdapat beberapa problematika baik dari segi landasan yuridis maupun landasan sosiologis.

Melihat keabsahan courtroom television dari aspek yuridis dari adanya asas terbuka untuk umum, terbukanya persidangan ini pada dasarnya Negara Indonesia sebagai negara hukum menghendaki adanya penegakan rule of law yang betul-betul dapat dilaksanakan secara objektif dan hakim dalam menangani suatu perkara dilarang berpihak kepada salah satu pihak.Apabila hakim dalam menangani suatu perkara dapat menempatakan dirinya sebagai hakim yang baik atau tidak berpihak kepada salah satu pihak, maka hakim akan dapat memenuhi kebutuhan masyarakat khususnya terhadap para pencari keadilan dan dapat dijadikan tumpuan akhir untuk menyelesaikan perkara-perkara yang dihadapi oleh masyarakat dengan cara yang seadil-adilnya.

Asas terbukanya persidangan ini dimaksudkan agar publik dapat menyaksikan langsung jalannya persidangan sekaligus menjadi pengawas hakim dalam menangani suatu perkara objektif apa berpihak kepada salah satu pihak atau tidak. Dalam praktik persidangan yang terbuka untuk umum, persidangannya dilaksanakan dalam ruangan yang pintunya terbuka dan setiap orang tanpa terkecuali dapat menyaksikan jalannya persidangan. Hal tersebut jelas terlihat dalam Pasal 153 ayat (3) yang berbunyi sebagai berikut "Untuk keperluan pemeriksaan hakim ketua sidang membuka sidang dan menyatakan terbuka untuk umum kecuali dalam perkara mengenai kesusilaan atau terdakwanya anak-anak". Mengingat dalam Pasal 28 D ayat (1) Undang Undang Dasar Negara Republik Indoneia Tahun 1945 (UUD 1945) menyebutkan "Setiap orang berhak atas pengakuan, jaminan, perlindungan dan kepastian hukum yang adil serta perlakuan yang sama di hadapan hukum”, secara penafsiran penulis maka, sidang terbuka untuk umum merupakan bagian dari hak terdakwa yang tidak terlepas. 
Landasan yuridis selajutnya mengenai perkembangan teknologi informasi untuk pengetahuan dibidang hukum acara pidana demi meningkatkan kualitas diri. Hal tersebut merupakan bagian dari hak asasi manusia yang terkandung dalam Pasal 28 C ayat (1) UUD 1945yaitu "Setiap orang berhak mengembangkan diri melalui pemenuhan kebutuhan dasarnya, berhak mendapat pendidikan dan memperoleh manfaat dari ilmu pengetahuan dan teknologi, seni dan budaya, demi meningkatkan kualitas hidupnya dan demi kesejahteraan umat manusia", dan Pasal 28 F UUD 1945 menyebutkan bahwa "Setiap orang berhak untuk berkomunikasi dan memperoleh informasi untuk mengembangkan pribadi dan lingkungan sosialnya, serta berhak untuk mencari, memperoleh, memiliki, menyimpan, mengolah, dan menyampaikan informasi dengan menggunakan segala jenis saluran yang tersedia”.

Sebagai suatu kesatuan dalam Pasal 28 UUD 1945 maka yang dapat memperoleh dan menyampaikan informasi adalah Pers, hal ini tersirat dalam Undang Undang Republik Indonesia Nomor 40 Tahun 1999 Tentang Pers (UU Pers). Pengertian Pers terdapat dalam Pasal 1 angka 1 UU Pers yaitu "Pers adalah lembaga sosial dan wahana komunikasi massa yang melaksanakan kegiatan jurnalistik meliputi mencari, memperoleh, memiliki, menyimpan, mengolah, dan menyampaikan informasi baik dalam bentuk tulisan, suara, gambar, suara dan gambar, serta data dan grafik maupun dalam bentuk lainnya dengan menggunakan media cetak, media elektronik, dan segala jenis saluran yang tersedia". Pers yang juga melaksanakan kontrol sosial sangat penting pula untuk mencegah terjadinya penyalahgunaan kekuasaan baik korupsi, kolusi, nepotisme, maupun penyelewengan dan penyimpangan lainnya. Dalam melaksanakan fungsi, hak, kewajiban dan peranannya, pers menghormati hak asasi setiap orang, karena itu dituntut pers yang profesional dan terbuka dikontrol oleh masyarakat (kepentingan umum). Peranan Pers terdapat dalam Pasal 6 UU Pers yaitu "Pers nasional melaksanakan peranannya sebagai berikut : a. memenuhi hak masyarakat untuk mengetahui; b. menegakkan nilai-nilai dasar demokrasi, mendorong terwujudnya supremasi hukum, dan Hak Asasi Manusia, serta menghormat kebhinekaan; c. mengembangkan pendapat umum berdasarkan informasi yang tepat, akurat dan benar; d. melakukan pengawasan, kritik, koreksi, dan saran terhadap hal-hal yang 
berkaitan dengan kepentingan umum; e. memperjuangkan keadilan dan kebenaran;".

Landasan sosiologis dengan adanya konsep courtroom television memiliki fungsi pengawasan didalam persidangan perkara pidana. Fungsi pengawasan dalam hal ini dimiliki oleh Dewan Perwakilan Rayat yang dipertegas dalam Pasal $20 \mathrm{~A}$ ayat (1) UUD 1945 yakni "Dewan Perwakilan Rakyat memiliki fungsi legislasi, fungsi anggaran, dan fungsi pengawasan”, yang merupkan representatif dari rakyat itu sendiri. Jadi secara analogi bahwa rakyat wajib mengawasi setiap lembaga atau kekuasaan yang menerima anggaran dari hasil pajak yang dibayarkan oleh rakyat. Secara teknis dan teknologis, maka Pers sebagai teknis dalam memperoleh dan menyampaikan informasi, dan secara teknologis, televisi, radio atau streaming internet sebagai suatu alat penyampaian dari pengawasan. Bahkan bila diperlukan Pemerintah Daerah bekerja sama dengan TVRI atau lembaga stasiun televisi untuk mengkhususkan menyiarkan secara langsung setiap acara di persidangan peradilan pidana.

Penguatan konsep courtroom television harus dibarengi dengan landasan filosofis, dengan adanya pembaharuan hukum pidana di Indonesia harus dilandaskan pada tujuan Nasional yang ingin dicapai oleh bangsa Indonesia. Tujuan Nasional tersbut adalah untuk melindungi segenap bangsa Indonesia dan seluruh tumpah darah Indonesia, memajukan kesejahteraan umum, mencerdaskan kehidupan bangsa, dan ikut melaksanakan ketertiban dunia yang berdasarkan kemerdekaan, perdamaian abadi dan keadilan sosial. Landasan filosofis ini menjadikan konsep courtroom television melindungi masyarakat (terdakwa yang belum di vonis bersalah berdasarkan putusan pengadilan yang berkekuatan hukum tetap adalah masyarakat yang wajib diberikan perlindungan secara jasmani dan rohani) dari gangguan keseimbangan keselarasan berbagai kepentingan dan nilai akibat dari adanya kejahatan dan harus memperoleh ".......access to justice and fair treatment, restitution, compensation and assistance" ${ }^{\text {"7 }}$

${ }^{7}$ Jan J.M Van Dijk, Introducing Victimology, (Amsterdam: the $9^{\text {th }}$ International Symposium Of The World Society Of Victimology, 1997), Ed. Naskah Akademik Rancangan KUHAP 


\section{Pelaksanaan Courtroom Television Dalam Peradilan Pidana Dengan Agenda}

Saksi

Seperti yang telah dikemukakan, bahwa courtroom television secara landasan yuridis, sosiologis dan filosofis telah mendapatkan restu dari Konstitusi, KUHAP serta UU Pers. Bagi lembaga peradilan, pelaksanaan courtroom television harus dimaknai sebagai bentuk partisipasi pers atau media terhadap upaya penegakan hukum mewakili masyarakat (representatif dari DPR). Pelaksanaan courtroom television memang seharusnya terus dilakukan oleh pers atau media, karena salah satu fungsi pers adalah menyajikan informasi seakurat mungkin serta dalam rangka fungsi pengawasan. Pers atau media yang mampu menjalankan fungsi pengawasan tersebut dapat memberikan dorongan bagi lembaga peradilan untuk mewujudkan independensi peradilan yang berarti menciptakan peradilan yang tidak memihak, akuntabel, transparan, mandiri, profesional dan kemudahan akses pelayanan keadilan bagi semua masyarakat. Dalam rangka menumbuhkan kembali kepercayaan masyarakat terhadap penegakan hukum oleh lembaga peradilan maka lembaga peradilan khususnya hakim tidak perlu lagi melihat pers sebagai musuh yang mencampuri urusan internal peradilan, namun sebagai mitra yang dapat mendekatkan peradilan dengan masyarakat pencari keadilan.

Skema: courtroom television

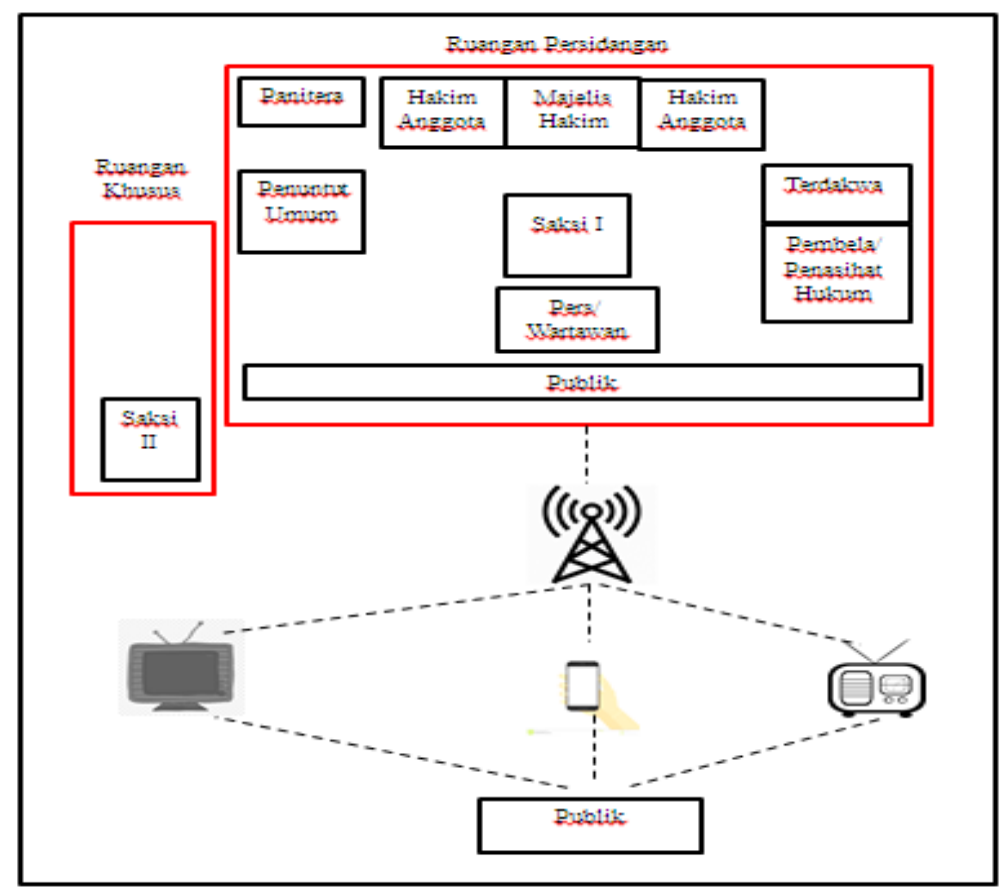


Penyatuan dari beberapa unsur antara lembaga peradilan dengan pers masih menyisakan konflik antara konsep courtroom television dengan salah satu agenda atau acara pemeriksaan peradilan pidana yaitu mengenai acara pembuktian saksi. Secara umum, tahapan peridangan peradilan pidana diawali dengan pembacaan dakwaan oleh JPU, pembacaan eksepsi oleh terdakwa/penasehat hukum, pembacaan replik oleh JPU, pembacaan duplik oleh terdakwa/ penasehat hukum, pembacaan putusan sela oleh Majelis Hakim (fakultatif), pemeriksaan alat bukti diawali degan pemeriksaan saksi, keterangan ahli (fakultatif), surat, petunjuk dan keterangan terdakwa, pembacaan tuntutan oleh JPU, pembacaan pledoi oleh terdakwa/ penasehat hukum, pembacaan putusan oleh Hakim.

Proses acara persidangan peradilan pidana sangat penting, tetapi yang menjadi penitik beratkan dari keseluruhan proses acara persidangan peradilan pidana adalah pembuktian. Pembuktian yang paling utama adalah keterangan saksi, saksi yang dihadirkan minimal 2 orang seperti adagium unus testis nullua testis, dimana keterangan saksi tersebut saling memperkuat. Pengertian saksi dapat dilihat dalam Pasal 1 angka 26 KUHAP yang menyatakan "Saksi adalah seseorang dapat memberikan keterangan guna kepentingan penyidikan, penuntutan dan peradilan suatu perkara pidana yang ia dengar sendiri, ia lihat sendiri dan ia alami sendiri”. Sedangkan menurut Pasal 160 ayat (4) KUHAP menyatakan, "jika pengadilan menganggap perlu seorang saksi atau ahli wajib sumpah atau berjanji sesudah saksi atau ahli tersebut selesai memberikan keterangan", penyusunan semacam ini dilakukan secara assertoris.

Seperti diketahui dalam pembuktian tidaklah mungkin dan dapat tercapai kebenaran mutlak (absolut). Semua pengetahuan hanya bersifat relatif, yang didasarkan pengalaman, penglihatan dan pemikiran yang tidak selalu pasti benar. Keterangan saksi adalah merupakan satu dari lima alat bukti yang dibutuhkan dalam mengungkapkan perkara pidana. Dalam Pasal 185 KUHAP menyebutkan: "Keterangan saksi sebagai alat bukti ialah apa yang saksi nyatakan di sidang pengadilan”. Keterangan saksi harus diberikan atau dibacakan dimuka persidangan agar hakim dapat menilai bahwa keterangan yang diberikan oleh saksi tidak keterangan palsu. Tidak semua keterangan saksi mempunyai nilai sebagai alat bukti. Keterangan saksi yang mempunyai nilai sebagai alat bukti ialah keterangan 
saksi yang sesuai dengan apa yang dijelaskan pada Pasal 1 angka 27 KUHAP yaitu keterangan saksi mengenai suatu peristiwa yang saksi lihat sendiri, saksi dengar sendiri, saksi alami sendiri serta menyebut alasan dari pengetahuannya itu. Selain itu dengan adanya adagium unus testis nullua testis yang artinya satu saksi bukan saksi, dapat ditafsirkan bahwa saksi dalam agenda pembuktian saksi haruslah lebih dari satu orang.

Keterangan saksi dalam agenda perkara pidana harus diperiksa satu per satu seperti yang tercantum dalam Pasal 160 ayat (1) huruf a KUHAP yaitu "Saksi dipanggil ke dalam ruang sidang seorang demi seorang menurut urutan yang dipandang sebaik-baiknya oleh hakim ketua sidang setelah mendengar pendapat penuntut umum, terdakwa atau penasihat hukum". Saksi tidak diperbolehkan saling mendengarkan keterangan. Hal ini untuk menghindari saksi saling memengaruhi sehingga tidak memberikan keterangan yang seharusnya, sebagaimana yang mereka dengar sendiri, mereka lihat sendiri, atau mereka alami sendiri. Apabila diperlukan, hakim dapat menyuruh saksi ke luar dari ruang sidang, sedangkan saksi yang telah diperiksa wajib keluar dari ruang persidangan. Hal ini dilakukan apabila terdapat kemungkinan saksi yang akan diperiksa selanjutnya menjadi tidak bebas, merasa canggung, atau merasa takut dalam memberikan keterangannya apabila didengar oleh saksi lainnya.

Apabila dalam hal ini pelaksanaan konsep courtroom television dalam persidangan perkara pidana, pada saat agenda pembuktian saksi. Maka pada saat salah satu saksi sedang diperiksa di persidangan, saksi yang lain dapat mengetahui melalui media elektronik televisi atau streaming internet. Sehingga pengamalan dari Pasal 160 ayat (1) huruf a KUHAP ini perlu ditafsirkan kembali. Hal lain bisa dilakukan oleh Pemerintah dengan cara membuat suatu ruangan khusus dimana para saksi ditempatkan di ruangan tersebut tanpa adanya koneksi internet.

\section{PENUTUP}

\section{Kesimpulan}

Pelaksanaan konsep courtroom television sudah pernah dilaksanakan pada tahun 2009 walaupun tidak utuh sepenuhnya, dan pada tahun 2017 pelaksanaan 
konsep courtroom television telah terealisasi dengan baik. Konsep courtroom television ini telah sesuai dengan hirarki Peraturan Perundang Undangan dengan berlandaskan asas sidang terbuka untuk umum, UUD 1945, KUHAP serta UU Pers perlu dikaji lebih mendalam, sewajarnya diperlukan peraturan pelaksana demi menjamin kepastian hukum serta terciptanya kolaborasi antara lembaga peradilan, pers, stasiun televisi, stasiun radio atau provider internet dan juga masyarakat dengan fungsi pengawasan.

Pelaksanaan konsep courtroom television tidak sejalan dengan rumusan Pasal 160 ayat (1) huruf a KUHAP mengenai pemeriksaan saksi di ruang persidangan seorang demi seorang. Hal itu dikarenakan dengan adanya konsep courtroom television maka kesaksian saksi yang sedang diperiksa di persidangan dapat diketahui oleh saksi yang akan diperiksa selanjutnya, hal ini akan memengaruhi keterangan yang seharusnya, sebagaimana yang mereka dengar sendiri, mereka lihat sendiri, atau mereka alami sendiri. Pelaksanaan konsep courtroom television di Indonesia memiliki fungsi pengawasan dan pengembangan pengetahuan serta teknologi demi kualitas sumber daya manusia. Sehingga selayaknya Pasal 160 ayat (1) huruf a KUHAP ini perlu dikaji dan ditafsirkan melalui SEMA sebagai pengamalan dari asas sidang terbuka untuk umum, UUD 1945, KUHAP serta UU Pers.

\section{DAFTAR PUSTAKA}

\section{Buku}

Lambert, Paul. Television Courtroom Broadcasting; Distraction Effects And Eye Tracking. Chicago:The University Chicago Press, 2012.

Makarim, Edmon. Kompilasi Hukum Telematika, Jakarta: P.T. Raja Grafindo Persada, 2003.

Pasek Diantha, I Made. Metode Penelitian Hukum Normatid Dalam Justifikasi Teori Hukum. Jakarta: Prenada Media Group, 2017.

Susanto, Anthon F. Penelitian Hukum Transformatif-Partisipatoris. Malang: Setara Press, 2015.

Yahya Harahap, M. Pembahasan Permasalahan dan Penerapan KUHP: Pemeriksaan Sidang Pengadilan, Banding, Kasasi, dan Peninjauan Kembali. Edisi Revisi. Jakarta: Sinar Grafika, 2012. 


\section{$\underline{\text { Jurnal }}$}

Supasti Dharmawan, Ni Ketut.. d.k.k. (2015). Keberadaan Pemegang Saham Dalam Rups Dengan Sistem Teleconference Terkait Jaringan Bermasalah Dalam Perspektif Cyber Law. Udayana Master Law Jurnal.4 (1). h. 190.

\section{Peraturan Perundang Undangan}

Undang Undang Dasar Negara Republik Indonesia

Undang Undang Nomor 8 Tahun 1981 Tentang Kitab Undang Undang Hukum Acara Pidana

Undang Undang Republik Indonesia Nomor 40 Tahun 1999 Tentang Pers (Tambahan Lembaran Negara Republik Indonesia nomor 3887 Tahun 1999)

Naskah Akademik Rancangan Kitab Undang Undang Hukum Acara Pidana (KUHAP) 